\title{
Post-transcriptional regulation of $\mathrm{Ca}^{2+}$-activated $\mathrm{K}^{+}$channel $\mathrm{K}_{\mathrm{ca}} 3.1$ by histone deacetylase in $\mathrm{CD}^{+}$cells of the inflammatory bowel disease model mice
}

\author{
Miki Matsui ${ }^{1}$, Kyoko Terasawa ${ }^{1}$, Hiroaki Kito ${ }^{2}$, Masanori Fujii ${ }^{1}$, Susumu Ohya ${ }^{1,2}$ \\ ${ }^{I}$ Department of Pharmacology, Kyoto Pharmaceutical University, Japan, ${ }^{2}$ Department of Pharmacology, Graduate \\ School of Medical Sciences, Nagoya City University, Japan
}

Background: The intermediate-conductance $\mathrm{Ca}^{2+}$-activated $\mathrm{K}^{+}$channel $\left(\mathrm{K}_{\mathrm{Ca}} 3.1\right)$ is one of the key molecules that modulate $\mathrm{Ca}^{2+}$ signaling by controlling $\mathrm{Ca}^{2+}$ entry through $\mathrm{Ca}^{2+}$ release activated $\mathrm{Ca}^{2+}$ channels in $\mathrm{T}$ cell. Our previous study demonstrated that the up-regulation of $\mathrm{K}_{\mathrm{Ca}} 3.1$ in $\mathrm{CD}^{+} \mathrm{T}$ cells was involved in the pathogenesis of inflammatory bowel disease (IBD), and a significant decrease in IBD disease severity was elicited by administration of the $\mathrm{K}_{\mathrm{Ca}} 3.1$ inhibitor, TRAM-34. $\mathrm{K}_{\mathrm{Ca}} 3.1$ is possible therapeutic target for IBD, however, the mechanism of $\mathrm{K}_{\mathrm{Ca}} 3.1$ up-regulation in CD4 ${ }^{+} \mathrm{T}$ cells remains unclear. Recent studies showed that histone deacetylase inhibition in vivo decreases disease responses in IBD. We examined the involvement of HDACs in up-regulation of $\mathrm{K}_{\mathrm{Ca}} 3.1$ in $\mathrm{CD}^{+} \mathrm{T}$ cells from IBD model mice.

Methods: The mouse model of IBD was prepared by exposing male C57BL/6 mice to 5\% dextran sulfate sodium for 7 days. Isolated splenocytes from IBD model mice were cultivated in the presence of the lectin, concanavalin A (Con A, 5 $\mu \mathrm{g} / \mathrm{mL}$ ) for $48 \mathrm{hr} .24$ hours after the cultivation, cell suspensions were treated with vehicle control or HDAC inhibitors. $\mathrm{CD}^{+} \mathrm{T}$ cells were then isolated using the Dynabeads technology. The expression levels of $\mathrm{K}_{\mathrm{Ca}} 3.1$, HDACs, and $\mathrm{K}_{\mathrm{Ca}} 3.1$ related genes were determined by real-time PCR and/or western blot assays. $\mathrm{K}_{\mathrm{Ca}} 3.1$ inhibitor-induced depolarization responses were monitored by voltage-sensitive dye imaging. All HDAC inhibitors were supplied by Professor Suzuki (Kyoto Prefectural University of Medicine, Japan).

Results: Real-time PCR assay showed the significant level expression of class I HDAC members (HDAC1, 2 and 3) in $\mathrm{CD}^{+} \mathrm{T}$ cells of normal mice, and they were significantly up-regulated in IBD model. Several activator protein 1 (AP1) components that are possible regulators of $\mathrm{K}_{\mathrm{Ca}} 3.1$ transcription also up-regulated in IBD model. The treatment with the pan-HDAC inhibitor vorinostat $(1 \mu \mathrm{M})$ induced both down-regulation of $\mathrm{K}_{\mathrm{Ca}} 3.1$ and decrease in $\mathrm{K}_{\mathrm{Ca}} 3.1$ activity in CD4 ${ }^{+}$ T cells. Moreover, the selective inhibition of HDAC2 and HDAC3 significantly down-regulated $\mathrm{K}_{\mathrm{Ca}} 3.1$.

Conclusion: These findings suggest that $\mathrm{HDAC} 2 / 3$ may be involved in the post-transcriptional regulation of $\mathrm{K}_{\mathrm{Ca}} 3.1$ in inflammatory $\mathrm{CD} 4^{+}$cells. 